Steven Iliffe, et al, 'Provision of NHS generalist and specialist services to care homes in England: review surveys', Primary Health Care Research \& Development, Vol. 17(2): 122-137, first published on line May 5, 2015. This article has been published in a revised form in Primary Health Care Research \& Development http://dx.doi.org/10.1017/S1463423615000250

This version is free to view and download for private research and study only. Not for re-distribution, re-sale or use in derivative works. (C) Steve lliffe et al.

Cambridge University Press 2015 


\section{Provision of NHS generalist and specialist services to care homes in England: review of surveys.}

Steve lliffe, Department of Primary Care \& Population Health, University College London

s.iliffe@ucl.ac.uk

Susan L Davies, Centre for Research in Primary and Community Care, University of Hertfordshire s.l.davies@herts.ac.uk

Adam L Gordon, Division of Rehabilitation and Ageing, University of Nottingham, UK Adam.Gordon@nottingham.ac.uk

Justine Schneider, Institute of Mental Health, University of Nottingham, UK.

Justine.Schneider@nottingham.ac.uk

Tom Dening, Institute of Mental Health, University of Nottingham, UK

Tom.Dening@nottingham.ac.uk

Clive Bowman, School of Health Sciences, City University, London, UK.

bowmanclive@gmail.com

Heather Gage, School of Economics, University of Surrey, UK. h.gage@surrey.ac.uk

Finbarr C Martin, Division of Health and Social Care Research, Kings College London, UK Finbarr.Martin@gstt.nhs.uk

John RF Gladman, Division of Rehabilitation and Ageing, University of Nottingham

John.Gladman@nottingham.ac.uk

Christina Victor, Dept of Community Health Nursing and Health Studies, Brunel University,

UK Christina.Victor@brunel.ac.uk

Julienne Meyer, School of Health Sciences, City University, London, UK.

J.Meyer@city.ac.uk>

Claire Goodman, Centre for Research in Primary and Community Care, University of

Hertfordshire c.goodman@herts.ac.uk

for the OPTIMAL research study

Corresponding author: Steve Iliffe, Department of Primary Care \& Population Health, University College London s.iliffe@ucl.ac.uk 


\section{ABSTRACT}

Background: The number of beds in care homes (with and without nurses) in the UK is three times greater than the number of beds in NHS hospitals. Care homes are predominantly owned by a range of commercial, not-for-profit or charitable providers and their residents have high levels of disability, frailty and co-morbidity. NHS support for care home residents is very variable, and it is unclear what models of clinical support work and are cost effective.

Objectives: To critically evaluate how the NHS works with care homes.

Methods: A review of surveys of NHS services provided to care homes that had been completed since 2008. It included published national surveys, local surveys commissioned by Primary Care organisations, studies from charities and academic centres, grey literature identified across the nine government regions, and information from care home, primary care and other research networks. Data extraction captured forms of NHS service provision for care homes in England in terms of frequency, location, focus and purpose.

Results: Five surveys focused primarily on general practitioner services, and ten on specialist services to care home. Working relationships between the NHS and care homes lack structure and purpose and have generally evolved locally. There are wide variations in provision of both generalist and specialist healthcare services to care homes. Larger Care home chains may take a systematic approach to both organising access to NHS generalist and specialist services, and to supplementing gaps with in-house provision. Access to dental care for care home residents appears to be particularly deficient.

Conclusions: Historical differences in innovation and provision of NHS services, the complexities of collaborating across different sectors (private and public, health and social care, general and mental health), and variable levels of organisation of care homes, all lead to persistent and embedded inequity in the distribution of NHS resources to this population. Clinical commissioners seeking to improve the quality of care of care home residents need to consider how best to provide fair access to health care for older people living in a care home, and to establish a specification for service delivery to this vulnerable population.

Key words: care homes $\bullet$ integrated health and social care $\bullet$ general practice $\bullet$ community nursing •underserved communities $\bullet$ inequalities $\bullet$ co-morbidity • equity 


\section{A note on health and social care systems.}

This study refers to services in England, which has a purchaser-provider split in the planning and funding of services on the one hand, and their provision..

Primary care organisations (previously called Primary Care Trusts and now called Clinical Commissioning Groups) allocate resources to providers organised as community or hospital Trusts. These providers manage community nursing, rehabilitation and pharmacy services. Clinical commissioners are mostly general practitioners.

Places in care homes (with or without nursing) may be self-financed by the resident or funded by local government.

The quality of care homes is assessed by the Care Quality Commission, a government regulatory body. 


\section{BACKGROUND}

In England, long term care for older people not living in their own homes is mostly provided by independently- owned (for-profit and not-for-profit) care homes, which include $90 \%$ of the 10,331 care homes that accommodate 376,250 people, making a sector that in terms of bed numbers is three times the size of the National Health Service (NHS) hospital bed complement. Care homes may or may not have on-site nursing, and were previously called 'residential' or 'nursing' homes. The typical care home resident is female, 85 or more years old, in the last phase of her life, living with cognitive impairment and in receipt of seven or more medications. A substantial proportion live with depression, impaired mobility and persistent pain Goodman \& Davies 2011, BGS 2011, Gordon et al 2013)]. Care home residents rely on general practice for both their medical care and for access to specialist services.

The care home sector is diverse, varying in size, ownership, funding sources, focus, organisational culture and presence or absence of nursing on site (Goodman et al 2011, Davies et al 2011). Across the NHS there are numerous approaches to provision of health care for residents, including: general medical care provided by general practices, community services linked to homes, outreach clinics, care home specialist nurses or support teams, pharmacist-led services, designated NHS hospital beds and enhanced payment schemes for General Practitioners (GPs) to undertake additional work (Hayes \& Martin 2004, Donald et al 2008, ECCA 2008 Joseph Rowntree Foundation 2008, Lawrence \& Banerjee 2010, Gladman 2010, Gage et al 2010, Thompsell 2011). As a result of this diversity, some care home residents may have unequal access to NHS resources, particularly those that offer specialist expertise in dementia, rehabilitation and end of life care (Jacobs et al 2001, Glendinning et al 2002, Goodman et al 2003, Goodman 2005, Alzheimer's Society 2007, Steve 2009, Robbins et al 2013) .

A recurring policy concern is that the ways in which problems are defined and services organised by the NHS do not always reflect the needs and wants of older people and their relatives, nor those of care home staff (Goodman et al 2013). Szczepura and colleagues (Szczepura et al 2008) summarized the evidence on best ways to improve medical care in care homes without on-site nursing, and concluded that the provider needed to be more proactive with a focus on prevention of health crises, complications or worsening disability, and that primary care should work strategically with care homes to achieve these goals. There is evidence, for example, that targeted support by local NHS services in end of life care and in medication management can improve outcomes for care home residents 
(Szczepura et al 2011). However, despite this evidence base and our understanding of the barriers and facilitators to collaborative working, there is uncertainty about how to sustain effective joint working between the NHS and care homes functioning as independent providers of care for the oldest old.

The 2010 Care Quality Commission (CQC) survey (Carter 2011) of Primary Care Trusts found that patterns of NHS services for care homes were disparate and lacked coherence, with limited ability to support reviews of care or audits of quality or of cost-effectiveness. At the time of the CQC survey $40 \%$ of Primary Care Trusts in England were using Local Enhanced Services payments to incentivise GP practices to provide services to care homes. However, the survey could not establish how many care homes benefitted from this extra investment, nor in what ways. For example, the same payments could have been used to develop and expand work in care homes or to close a gap in GP provision. The survey found no evidence of governance or outcome targets that were care-home specific.

A British Geriatrics Society (BGS) report on the quality of health care support for older people in care homes, published in 2011 , concluded that there was a need to clarify NHS obligations to care home residents (BGS 2011).There is no definitive evidence which dictates whether these activities will be better provided by enhanced primary care or specialist services but subsequent guidance for commissioners (BGS 2013) sets out a range of outcomes for residents, the NHS and care homes, how these outcomes may be achieved, and suggests how they may be monitored and evaluated

This paper explores the complex relationship between the NHS and care homes. It reports the findings of a survey of published and unpublished studies of the range, frequency and type of NHS service provision for care home residents. The study was carried out to establish a benchmark for further research into collaborative working between the two sectors. This study (OPTIMAL) is funded by the NIHR (HS\&DR Project code11/1021/02). 


\section{METHODS}

To obtain a comprehensive overview of the range, frequency and type of NHS service delivery and build on an earlier review of NHS involvement in care homes (Gage et al 2012), we reviewed surveys of how NHS services in England were provided to care homes completed since 2008. Document retrieval, review and scrutiny of papers and reports, information retrieval and preliminary analysis were carried out by two researchers. To be eligible for inclusion the surveys had to focus on health care delivery to care homes in the UK and had to be completed since 2008. This review updated the findings from the APPROACH national survey that focused on care homes without on-site nursing (Davies et al 2011).

We searched the following electronic databases; Medline (PubMed), CINAHL, BNI, EMBASE, Psyclnfo, DH Data, Kings Fund, In addition, we contacted care home related interest groups and used lateral search techniques, such as checking reference lists of relevant papers, and using the 'Cited by' option on Web of Science (WoS), Google Scholar and Scopus, and the 'Related articles' option on PubMed and WoS.

Research terms go here

Online searches were conducted on the websites of care home researchers known to the OPTIMAL team, voluntary sector providers of care homes, other care home organisations and their representative and professional organisations. Where possible the websites of NHS regional management structures (strategic health authorities) were searched to identify care home initiatives referred to in their annual reports (up to March 2013). However, as these were in a state of flux due to reorganisation not all websites were available. We also requested information through primary care and care home e-networks (e.g. My Home Life Network, National Care Home Research and Development Forum, the Primary Care Research Network (PCRN), clinical study groups of the Dementias \& Neurodegenerative Diseases Research Network (DeNDRoN), and the Age and Ageing network).

Electronic search results were downloaded into EndNote bibliographic software. Two reviewers independently (SD, CG) screened all titles and abstracts of citations identified by the electronic search, and extracted data from included studies using a standardised form. Data extraction was structured to capture forms of NHS service provision for care homes in England in terms of frequency, location, focus and purpose and, where possible, funding. 
Due to substantial heterogeneity in study design, interventions, participants and outcomes we did not pool studies in a meta-analysis. Instead a narrative summary of findings is provided. Since the paper is about a review of published literature, no approval was needed from an ethics committee

\section{RESULTS}

The searches identified 15 surveys, of which five focused on general practitioner service provision to care homes, whilst also collecting data on specialist services. The other ten focused on specialist services to care homes, or were topic-specific; for example, concerned with dementia or with end of life care. In the five surveys that concentrated on generalist provision data were collected from care home managers, with the exception of the Care Quality Commission study analysed by the British Geriatric Society (Carter 2011). Insight about how wider NHS provision was organised was limited in this subset of studies, although some information on geriatrician services was reported in the survey by Steves and colleagues (Steves et al 2009), and on dental care by the British Dental Association's survey (BDA 2012). Table 1 summarises these studies.

\section{Table 1 near here}

Most surveys focused on care homes, relied on care home managers to provide most of the information on service provision, together with input from other health and social care professionals, including GPs, geriatricians, primary care lead nurses, registered nurses working in care homes, other care home staff, and dentists. Studies of specialist services for care home residents are shown in Table 2.

\section{Table 2 near here}

Only two surveys included residents as participants, one of which also included relatives of residents who were unable to participate due to cognitive impairment. The main method of data collection was postal or online questionnaires, although some used face-to-face interviews with care home residents and telephone interviews with GPs.

We summarise the survey findings under the two headings used to present the surveys themselves: 'primary care' and 'specialist services'. 
Primary Care: Primary care was seen, in most studies, as key to the provision of good quality health care for care home residents, including end-of-life care, but there was no consensus about how GP and other primary care services should be organised in relation to the care homes. There was variability in services provided to care homes with, for example, some GPs providing regular medication reviews (6 monthly or yearly), while some did postadmission assessments. The majority of care homes surveyed worked with multiple practices and multiple GPs. The largest number of practices visiting one care home was 30 - although some had a single, designated general practitioner. Consultation arrangements were variable. Some GPs did weekly clinics, whilst others visited only on request. This variability was mirrored in family and residents' views; one survey found that only $56 \%$ reported good access to and support from GPs, with 55\% of staff also reporting that residents got enough support from general practitioners (CQC 2012).

The numbers of different types of nurses involved in working with care homes was striking. It was not possible to determine if there was a duplication of provision in some care homes and limited access to specialist nursing support for others. Eight types of nurses were identified as visiting care homes. District nurses were most frequently mentioned. Nursing services could be organised as a service for the care home (community psychiatric nurse, nurse practitioner, nurse consultant, falls prevention nurse, nurse led care home team) or provided on a resident by resident basis (district nurse, continence specialist, tissue viability, palliative care, Parkinson's disease nurse).

Specialist care: A common theme mentioned by care home managers was the difficulty experienced in accessing some specialist services, especially palliative care teams, geriatricians and old age psychiatrists. Accessing dental care was also reported as problematic in some places, and this was reflected in the CQC survey (Carter 2011) in which large numbers of relatives and residents reported that they were unsure how to access dental services. This was corroborated in the dentistry-specific surveys with Monaghan and Morgan finding that residents with their own teeth were much less likely to report regular dental check-ups (19\%) than older people living at home (Monaghan \& Morgan 2010). However, in some surveys, care homes reported good access to specialist services. Whilst surveys were able to measure the frequency of contact, very few addressed the quality and range of provision.

Despite the multiple services identified as having contact with care homes, one survey suggested that moving into a care home did not increase residents' access to NHS services 
(Darton 2011) . However, there was some evidence that care homes with nursing staff had greater access to geriatricians than did residential care homes. 
TABLE 1 - Summary of data extracted from surveys of generalist provision to care homes.

\begin{tabular}{|c|c|c|c|c|c|}
\hline $\begin{array}{l}\text { AUTHORS/TITLE } \\
\text { YEAR/ HOME TYPE }\end{array}$ & AIMS & SURVEY DETAILS & $\begin{array}{l}\text { SAMPLE SIZE } \\
\text { RESPONSE RATE }\end{array}$ & GP SERVICES & OTHER SERVICES \\
\hline $\begin{array}{l}\text { 1. Morris / Barchester } \\
\text { health care. 'Service } \\
\text { Review of Barchester } \\
\text { Care Homes' } 2008 \\
\text { (Morris 2008) } \\
\text { Nursing homes }\end{array}$ & $\begin{array}{l}\text { Do care home staff and } \\
\text { GPs get enough } \\
\text { information about new } \\
\text { residents? } \\
\text { Do GPs and care home } \\
\text { staff feel supported by } \\
\text { primary and secondary } \\
\text { care? }\end{array}$ & $\begin{array}{l}\text { Face-to-face or telephone } \\
\text { interviews with } 11 \text { care home } \\
\text { managers and } 6 \text { GPs using } \\
\text { standardised questionnaires. } \\
\text { Service related questions } \\
\text { covered: GPs, tissue viability, } \\
\text { mental health, end of life care, } \\
\text { geriatrician, old age } \\
\text { psychiatry, audiology, } \\
\text { ophthalmology, podiatry, } \\
\text { physiotherapy, occupational } \\
\text { therapy and community } \\
\text { pharmacist. }\end{array}$ & $\begin{array}{l}11 \text { care homes } \\
\text { selected to reflect a } \\
\text { range in terms of } \\
\text { size, location and } \\
\text { residents. } \\
\text { Size ranged from } 39 \\
-118 \text { beds }(n=9)\end{array}$ & $\begin{array}{l}\text { From nursing home } \\
\text { interviews ( } n=9 \text { ) } \\
7 / 9 \text { care homes had } \\
\text { a single designated } \\
\text { GP; } 5 \text { did weekly } \\
\text { clinics, } 1 \text { visited } \\
\text { daily and the other } \\
2 \text { weekly } \\
\text { From GP interviews } \\
\text { ( } n=6 \text { ) } \\
3 / 6 \text { did either yearly } \\
\text { or six monthly } \\
\text { medication reviews }\end{array}$ & $\begin{array}{l}\text { - All care homes had access to tissue } \\
\text { viability support } \\
\text { - All care homes had access to } \\
\text { support with mental } \\
\text { health/behavioural problems. } \\
\text { All homes had access to an } \\
\text { ophthalmologist or optician } \\
\text { No care homes had access to } \\
\text { occupational therapy services } \\
\text { - No care homes had access to a } \\
\text { community pharmacist } \\
\text { According to GPs } \\
\text { - } 5 / 6 \text { care homes had access to } \\
\text { palliative care support. } \\
\text { - } 3 \text { care homes had access to both } \\
\text { the geriatrician and old age } \\
\text { psychiatrist the others had no or ad } \\
\text { hoc access } \\
\text { - } 4 / 6 \text { homes had access to audiology } \\
\text { - } 4 / 6 \text { homes had access to podiatry, } \\
2 \text { of which were provided by the } \\
\text { care home organisation } \\
-3 / 6 \text { had access to a } \\
\text { physiotherapist which they } \\
\text { provided }\end{array}$ \\
\hline $\begin{array}{l}\text { 2. Nottingham county } \\
\text { NHS/ } \\
\text { Chikura. 'Care homes } \\
\text { project' } 2010 \text { (Chikura } \\
\text { 2010). }\end{array}$ & $\begin{array}{l}\text { To conduct a review of } \\
\text { current service provision } \\
\text { to residents in } 252 \text { care } \\
\text { homes across the } \\
\text { county. }\end{array}$ & $\begin{array}{l}\text { Postal survey. } \\
\text { Data was collected on } 20 \\
\text { services including: Falls, GP, } \\
\text { pharmacist, physiotherapy, }\end{array}$ & $\begin{array}{l}\mathrm{N}=252-118 \\
\text { responses ( } 47 \% \\
\text { response rate) }\end{array}$ & $\begin{array}{l}\text { All homes allowed } \\
\text { their residents to } \\
\text { register with the } \\
\text { practice of their } \\
\text { choice - (one care }\end{array}$ & $\begin{array}{l}\text { - } 97 \% \text { of care homes had access to } \\
\text { pharmacy, DN } 92 \% \text {, Dietician } 89 \% \text {. } \\
\text { - Most services were available on } \\
\text { request rather than routinely with } \\
\text { the exception of pharmacists. }\end{array}$ \\
\hline
\end{tabular}




\begin{tabular}{|c|c|c|c|c|c|}
\hline $\begin{array}{l}\text { AUTHORS/TITLE } \\
\text { YEAR/ HOME TYPE }\end{array}$ & AIMS & SURVEY DETAILS & $\begin{array}{l}\text { SAMPLE SIZE } \\
\text { RESPONSE RATE }\end{array}$ & GP SERVICES & OTHER SERVICES \\
\hline $\begin{array}{l}\text { Nursing homes and } \\
\text { homes without nursing }\end{array}$ & & $\begin{array}{l}\text { OT, End of life, Mental health, } \\
\text { DN, Podiatry, Community } \\
\text { Geriatrician, Nurse } \\
\text { practitioner, Dietitian, } \\
\text { Community Matron, Long- } \\
\text { term conditions teams, Tissue } \\
\text { viability, Continence, } \\
\text { Dementia, optometrist, SALT, } \\
\text { stroke rehabilitation. }\end{array}$ & & $\begin{array}{l}\text { home was served by } \\
\text { up to } 16 \text { practices) } \\
\text { Most visits were on } \\
\text { request, some care } \\
\text { homes had regular } \\
\text { surgeries, others } \\
\text { found it hard to get } \\
\text { visits } \\
42 \% \text { of care homes } \\
\text { did not have regular } \\
\text { GP visits }\end{array}$ & $\begin{array}{l}\text {-The services which were available } \\
\text { to the least number of care homes } \\
\text { included Nurse Practitioner } 34 \% \text {, } \\
\text { Community Geriatrician } 42 \% \text { and } \\
\text { long term conditions team } 43 \% \text {. } \\
\text { - Only } 9 \% \text { of care reported access to } \\
\text { a community geriatrician } \\
\text { - } 23 \% \text { of care homes could not } \\
\text { access SALT, physiotherapy or } \\
\text { occupational therapy services } \\
\text { - An example of specific care home } \\
\text { services included care home } \\
\text { coordinators, a nurse- led team } \\
\text { which worked closely with care } \\
\text { homes to liaise with GPs, } \\
\text { pharmacists and specialist nursing } \\
\text { services as well as offering training } \\
\text { and support to care homes, } \\
\text { medication reviews and links to the } \\
\text { community equipment team. }\end{array}$ \\
\hline $\begin{array}{l}\text { 3. Gage et al } \\
\text { 'Integrated working } \\
\text { between residential } \\
\text { care homes and } \\
\text { primary care: a survey } \\
\text { of care homes in } \\
\text { England'. } \\
2012 \text { (Gage et al 2012) } \\
\text { Care homes without } \\
\text { nursing }\end{array}$ & $\begin{array}{l}\text { APPROACH survey: To } \\
\text { establish the extent of } \\
\text { integrated working } \\
\text { between care homes } \\
\text { and primary and } \\
\text { community health and } \\
\text { social services. }\end{array}$ & $\begin{array}{l}\text { A self-completion, online } \\
\text { questionnaire of open and } \\
\text { closed questions designed by } \\
\text { the research team to establish } \\
\text { the primary health care } \\
\text { service provision to care } \\
\text { homes and their experience of } \\
\text { integrated working with those } \\
\text { services. }\end{array}$ & $\begin{array}{l}\text { Sent to a random } \\
\text { sample of residential } \\
\text { care homes in } \\
\text { England in } 2009 \\
\text { ( } n=621 \text { ) with more } \\
\text { than } 25 \text { bids, located } \\
\text { through the } \\
\text { regulator;- } 93 \text { out of } \\
587 \text { care homes } \\
\text { responded (16\% } \\
\text { response rate) }\end{array}$ & $\begin{array}{l}\text { All care homes } \\
\text { reported receiving } \\
\text { GP services - 79\% } \\
\text { stated they worked } \\
\text { with at least one } \\
\text { practice } \\
\text { Arrangements for } \\
\text { consultations varied } \\
\text { - some received } \\
\text { weekly GP clinics } \\
\text { whilst others } \\
\text { described }\end{array}$ & $\begin{array}{l}\text { - >90\% of homes reported using } \\
\text { DNs and opticians } \\
\text { - Other frequently accessed services } \\
\text { (>80\%) included CPNs, podiatrists } \\
\text { - Between half and three quarters } \\
\text { of homes reported visits from } \\
\text { continence nurses, pharmacists, } \\
\text { dentists, hearing services and old } \\
\text { age psychiatrists } \\
\text { - Difficulty accessing specialist } \\
\text { services was a consistent theme } \\
\text { across the care homes }\end{array}$ \\
\hline
\end{tabular}




\begin{tabular}{|c|c|c|c|c|c|}
\hline $\begin{array}{l}\text { AUTHORS/TITLE } \\
\text { YEAR/ HOME TYPE }\end{array}$ & AIMS & SURVEY DETAILS & $\begin{array}{l}\text { SAMPLE SIZE } \\
\text { RESPONSE RATE }\end{array}$ & GP SERVICES & OTHER SERVICES \\
\hline & & & & $\begin{array}{l}\text { difficulties in getting } \\
\text { GPs to visit the care } \\
\text { home } \\
8 \% \text { paid a retainer } \\
\text { GP, but retainers } \\
\text { were generally } \\
\text { perceived to be } \\
\text { unfair; } \\
81 \% \text { worked with } \\
\text { more than one } \\
\text { practice }\end{array}$ & \\
\hline $\begin{array}{l}\text { 4. Chris Quince, Senior } \\
\text { Policy Officer } \\
\text { Alzheimer's Society. } \\
\text { 'Low expectations: } \\
\text { Attitudes on choice, } \\
\text { care and community for } \\
\text { people with dementia } \\
\text { in care homes'. } 2013 \\
\text { (Quince 2013) } \\
\text { Care homes with and } \\
\text { without Nursing }\end{array}$ & $\begin{array}{l}\text { To explore attitudes on } \\
\text { choice, care and } \\
\text { community for people } \\
\text { with dementia in care } \\
\text { homes }\end{array}$ & $\begin{array}{l}81 \text { care homes - interviewed } \\
\text { staff/residents or observed } \\
\text { care being delivered to } 386 \\
\text { residents }\end{array}$ & $\begin{array}{l}\text { Targeted sample: } \\
144 \text { adults } 65+ \\
\text { observed or } \\
\text { interviewed, } 93 \\
\text { staff interviewed in } \\
27 \text { nursing homes } \\
153 \text { adults } 65+ \\
\text { observed or } \\
\text { interviewed, } 90 \text { staff } \\
\text { interviewed in } 27 \\
\text { homes without } \\
\text { nursing } \\
\text { NB Homes with } \\
\text { learning disabilities } \\
\text { were included in the } \\
\text { findings }\end{array}$ & $\begin{array}{l}\text { Some variability } \\
\text { between care } \\
\text { homes in GP } \\
\text { services and who } \\
\text { pays for these } \\
\text { services } \\
\text { - } 33 \% \text { of homes said } \\
\text { that GPs did not } \\
\text { provide post- } \\
\text { admission } \\
\text { assessments for } \\
\text { residents } \\
\text { - } 53 \% \text { said they } \\
\text { were provided and } \\
\text { paid for by the PCT } \\
\text { - } 44 \% \text { of care } \\
\text { homes had } \\
\text { scheduled surgeries } \\
\text { or visits from GPs. }\end{array}$ & Not covered by this review \\
\hline $\begin{array}{l}\text { 5. Carter } 2013 \text { report to } \\
\text { BGS }\end{array}$ & $\begin{array}{l}\text { What health care } \\
\text { services are }\end{array}$ & $\begin{array}{l}\text { An on-line survey conducted } \\
\text { by the CQC to seek }\end{array}$ & $\begin{array}{l}\mathrm{N}=152 \\
\text { The report noted }\end{array}$ & $\begin{array}{l}\text { With the exception } \\
\text { of } 35 \text { PCTs }(23 \%) \text {, all }\end{array}$ & $\begin{array}{l}\text {-There were significant variations in } \\
\text { specialist services to older people - }\end{array}$ \\
\hline
\end{tabular}




\begin{tabular}{|c|c|c|c|c|c|}
\hline $\begin{array}{l}\text { AUTHORS/TITLE } \\
\text { YEAR/ HOME TYPE }\end{array}$ & AIMS & SURVEY DETAILS & $\begin{array}{l}\text { SAMPLE SIZE } \\
\text { RESPONSE RATE }\end{array}$ & GP SERVICES & OTHER SERVICES \\
\hline $\begin{array}{l}\text { Failing the Frail: A } \\
\text { chaotic approach to } \\
\text { Commissioning } \\
\text { Healthcare Services for } \\
\text { Care Homes (Carter } \\
\text { 2011) Residential \& } \\
\text { nursing } \\
\text { Data collected by the } \\
\text { cQC through PCTs not } \\
\text { care homes and } \\
\text { analysed by the BGS }\end{array}$ & $\begin{array}{l}\text { commissioned by PCTs } \\
\text { for older people living in } \\
\text { care homes } \\
\text { NB Service provision } \\
\text { included older people } \\
\text { living in the community. } \\
\text { It was not always } \\
\text { possible to separate the } \\
\text { findings specifically for } \\
\text { care homes. The focus is } \\
\text { on commissioning } \\
\text { intentions rather than } \\
\text { the service received. }\end{array}$ & $\begin{array}{l}\text { information about health } \\
\text { services for care homes and } \\
\text { older people living in the } \\
\text { community in all PCTs in } \\
\text { England } 152 \text { in total. } \\
\text { The survey focussed on } 9 \text { key } \\
\text { services: geriatricians, } \\
\text { psychiatry, dietetics, } \\
\text { occupational therapy, } \\
\text { physiotherapy, podiatry, } \\
\text { continence, falls prevention } \\
\text { and tissue viability. } \\
\text { PCTs were also asked about } \\
\text { whether or not GPs provided } \\
\text { additional services for care } \\
\text { home residents. PCTs were } \\
\text { also asked for information on } \\
\text { the provision of enhanced GP } \\
\text { services. CQC selected seven } \\
\text { activities to assess how PCTs } \\
\text { used GPs to meet the } \\
\text { healthcare needs of residents } \\
\text { including: } \\
\text { - Health assessments on } \\
\text { admission } \\
\text { - Specialist assessments } \\
\text { - Regular visits } \\
\text { - Support with End-of-Life care } \\
\text { planning } \\
\text { - General support } \\
\text { - Liaison with other healthcare } \\
\text { professionals }\end{array}$ & $\begin{array}{l}\text { that answers to } \\
\text { some questions } \\
\text { were poor. 'Don't } \\
\text { knows' and missing } \\
\text { answers were } \\
\text { treated as negative } \\
\text { responses }\end{array}$ & $\begin{array}{l}\text { PCTs provided at } \\
\text { least one activity } \\
\text { considered to be an } \\
\text { enhanced activity. } \\
\text { Only } 51 \% \text { (77) of } \\
\text { PCTs had enhanced } \\
\text { service agreements } \\
\text { with GPs for work in } \\
\text { care homes } \\
67 \% \text { of PCTs did not } \\
\text { think care home } \\
\text { residents needed } \\
\text { additional } \\
\text { medication reviews. }\end{array}$ & $\begin{array}{l}52 \text { different combinations of } \\
\text { specialist service provision across } \\
\text { the PCTs } \\
\text {-Only } 65 \text { ( } 43 \% \text { ) of PCTs provided all } \\
\text { the services CQC considered to be } \\
\text { appropriate for all older people. } \\
\text {-Only } 91(60 \%) \text { of PCTs provided a } \\
\text { geriatrician service to all older } \\
\text { people. } \\
95 \% \text { of specialist services covered } \\
\text { both nursing and residential care } \\
\text { homes. } \\
\text {-Most specialist services undertook } \\
\text { scheduled visits to care homes, } \\
\text { supplementing request visits. } \\
\text {-Across the PCTs, the majority of } \\
\text { specialist services made visits on } \\
\text { request to both nursing and } \\
\text { residential homes, but less than half } \\
\text { made scheduled visits. Scheduled } \\
\text { visits were most commonly made } \\
\text { by the continence service, podiatry, } \\
\text { podiatry, dietetics and psychiatry } \\
\text { and least commonly made by the } \\
\text { tissue viability and falls services, } \\
\text { physiotherapy and occupational } \\
\text { therapy. } \\
\text {-Geriatricians also made few } \\
\text { scheduled visits but this was slightly } \\
\text { more common in nursing than } \\
\text { residential homes ( } 27 \% \text { v } 18 \% \text { ). } \\
\text { - Only } 24 \% \text { of services had a specific } \\
\text { pathway for care home residents } \\
\text { and referral arrangements are }\end{array}$ \\
\hline
\end{tabular}




\begin{tabular}{|l|l|l|l|l|}
\hline $\begin{array}{l}\text { AUTHORS/TITLE } \\
\text { YEAR/ HOME TYPE }\end{array}$ & AIMS & SURVEY DETAILS & $\begin{array}{l}\text { SAMPLE SIZE } \\
\text { RESPONSE RATE }\end{array}$ & GP SERVICES \\
\hline & & $\begin{array}{l}\text { - Additional medication } \\
\text { reviews }\end{array}$ & $\begin{array}{l}\text { OTHER SERVICES } \\
\text { people living at home. }\end{array}$ & \\
\hline
\end{tabular}


TABLE 2 - OPTIMAL study - Summary of data extracted from topic specific surveys.

\begin{tabular}{|c|c|c|c|c|c|}
\hline $\begin{array}{l}\text { AUTHORS/TITLE } \\
\text { YEAR, (HOME TYPE) }\end{array}$ & AIMS & SURVEY DETAILS & $\begin{array}{l}\text { SAMPLE SIZE/RESPONSE } \\
\text { RATE }\end{array}$ & GP SERVICES & OTHER SERVICES \\
\hline $\begin{array}{l}\text { 1. Steves et al } \\
\text { 'Geriatricians and care } \\
\text { homes: Perspectives } \\
\text { from Geriatric } \\
\text { Medicine Departments } \\
\text { and Primary Care } \\
\text { Trusts'. } 2009 \text { (Steves } \\
\text { et al 2009) } \\
\text { Nursing homes, homes } \\
\text { without nursing and } \\
\text { dual registered homes }\end{array}$ & $\begin{array}{l}\text { To test concordance } \\
\text { with the RCP RCN } \\
\text { and BGS } 2000 \\
\text { guidelines on clinical } \\
\text { practice for care } \\
\text { homes }\end{array}$ & $\begin{array}{l}\text { Complementary surveys for PCTs } \\
\text { and geriatric medicine } \\
\text { departments (GMDs) distributed } \\
\text { in summer/autumn } \\
2006 \text { to the lead clinician in each } \\
\text { GMD in England \& the lead nurse } \\
\text { in each PCT in England. }\end{array}$ & $\begin{array}{l}\text { Responses were received } \\
\text { from } 109 \text { of the } 167(65 \%) \\
\text { GMDs in England and } 141 \text { of } \\
\text { the } 303(47 \%) \text { PCTs. }\end{array}$ & & $\begin{array}{l}\text {-17 (15.7\%) of GMDs } \\
\text { specifically allocated sessions } \\
\text { to care home work, mostly } \\
\text { with nursing homes. } \\
\text { - Some PCTs reported funding } \\
\text { geriatricians' involvement in } \\
\text { care homes (18\%) but } 52 \% \text { of } \\
\text { PCTs ( } 74 \text { ) either required } \\
\text { geriatricians' involvement in } \\
\text { the admissions process and } \\
20 \% \text { in supporting on going } \\
\text { care or care home residents } \\
\text { (40\%) } \\
\text { - Most PCTs had a } \\
\text { standardised assessment for } \\
\text { admission to care homes with } \\
\text { nursing mainly completed by a } \\
\text { social worker and/or nurse } \\
\text { - } 24 \% \text { ( } 26 / 109 \text { ) of GMDs gave } \\
\text { ongoing input to care homes }\end{array}$ \\
\hline $\begin{array}{l}\text { 2. Monaghan and } \\
\text { Morgan 'Oral Health } \\
\text { Policy and access to } \\
\text { dentistry in care } \\
\text { homes'. } 2010 \\
\text { (Monaghan \& Morgan } \\
\text { 2010) } \\
\text { Nursing homes, homes } \\
\text { without nursing and } \\
\text { dual registered homes }\end{array}$ & $\begin{array}{l}\text { To explore the } \\
\text { factors which may } \\
\text { facilitate or impede } \\
\text { access to dental care } \\
\text { and arrangements } \\
\text { within care homes in } \\
\text { Wales }\end{array}$ & $\begin{array}{l}\text { All care homes in Wales invited } \\
\text { to take part } 90 \% \text { postal survey } \\
\text { with } 10 \% \text { random sample } \\
\text { interviewed face to face or by } \\
\text { telephone. Questions focused on } \\
\text { new residents, dental } \\
\text { assessment, and access to } \\
\text { routine and emergency care, } \\
\text { dental care facilities, oral } \\
\text { awareness, hygiene practice, diet } \\
\text { and nutrition. }\end{array}$ & $\begin{array}{l}673 \text { residential care homes, } \\
88 \text { nursing, and } 186 \text { dual. } \\
81 \% \text { response rate } 957 \text { out } \\
\text { of target population of } \\
1185 .\end{array}$ & $\begin{array}{l}\text { Not included in this } \\
\text { survey }\end{array}$ & $\begin{array}{l}\text { Across Wales - managers } \\
\text { reported more difficulty in } \\
\text { accessing routine than } \\
\text { emergency dental care. } \\
\text { - } 24 \% \text { of care homes reported } \\
\text { 'always' having problems } \\
\text { accessing routine dental care } \\
-18 \% \text { of care homes reported } \\
\text { 'always' having problems } \\
\text { accessing emergency dental } \\
\text { care }\end{array}$ \\
\hline
\end{tabular}




\begin{tabular}{|c|c|c|c|c|c|}
\hline $\begin{array}{l}\text { AUTHORS/TITLE } \\
\text { YEAR, (HOME TYPE) }\end{array}$ & AIMS & SURVEY DETAILS & $\begin{array}{l}\text { SAMPLE SIZE/RESPONSE } \\
\text { RATE }\end{array}$ & GP SERVICES & OTHER SERVICES \\
\hline $\begin{array}{l}\text { 3. PSSRU University of } \\
\text { Kent 'Study of care } \\
\text { home residents' and } \\
\text { relatives expectations } \\
\text { and experiences'. } 2011 \\
\text { (Darton R 2011) } \\
\text { Nursing homes and } \\
\text { homes without nursing }\end{array}$ & $\begin{array}{l}\text { To examine older } \\
\text { people's } \\
\text { expectations and } \\
\text { experiences of living } \\
\text { in a care home and } \\
\text { to collect } \\
\text { information from } \\
\text { relatives about } \\
\text { choosing a care } \\
\text { home }\end{array}$ & $\begin{array}{l}\text { Focus was on resident's decision } \\
\text { to move into a care home and } \\
\text { the difference between their } \\
\text { expectations and experiences } \\
\text { but some data was collected on } \\
\text { health service use before and } \\
\text { after the move. An initial } \\
\text { interview was conducted with a } \\
\text { follow up three months later. }\end{array}$ & $\begin{array}{l}\text { Random sample of } 150 \text { care } \\
\text { homes approached in } 6 \\
\text { regions of England, located } \\
\text { via the CQC website. } \\
605 / 900 \text { homes recruited, } \\
\text { (response rate } 67 \% \text { ). Data } \\
\text { were collected from } 69 \\
\text { residents and } 33 \text { relatives of } \\
\text { residents in } 46 \text { care homes. }\end{array}$ & $\begin{array}{l}\text { Since moving in } 80 \% \\
\text { of residents had had } \\
\text { a consultation with } \\
\text { a GP or a practice } \\
\text { nurse and } 30 \% \text { had } \\
\text { been to hospital } \\
\text { Since moving in } \\
\text { relatives reported } \\
\text { that } 92 \% \text { had had a } \\
\text { consultation with a } \\
\text { GP or a practice } \\
\text { nurse and } 46 \% \text { had } \\
\text { been to hospital. }\end{array}$ & $\begin{array}{l}\text { - Prior to admission over one } \\
\text { third of residents received } \\
\text { chiropody services but few } \\
\text { received other services. After } \\
\text { moving in, twice as many } \\
\text { receive chiropody services } \\
72 \% \text { and } 20 \% \text { reported } \\
\text { receiving physiotherapy. } \\
\text { However, few residents } \\
\text { received OT and none } \\
\text { received speech therapy. } \\
\text { - Relatives reported that a } \\
\text { higher proportion of resident } \\
\text { received chiropody services } \\
\text { after moving in, } 91 \% \text { vs } 63 \% \text {. } \\
\text { However, relatives reported } \\
\text { that residents were no more } \\
\text { likely to receive other therapy } \\
\text { services than before } \\
\text { admission. } \\
\text { - Relatives reported that } 79 \% \\
\text { of residents had hospital } \\
\text { treatment prior to moving in } \\
\text { and that the medical or } \\
\text { nursing care provided in the } \\
\text { home was of a higher } \\
\text { standard. }\end{array}$ \\
\hline $\begin{array}{l}\text { 4. Seymour et al } \\
\text { 'Do nursing homes for } \\
\text { older people have the } \\
\text { support they need to } \\
\text { provide end of life } \\
\text { care? A mixed }\end{array}$ & $\begin{array}{l}\text { To identify key } \\
\text { factors in the wider } \\
\text { health and social } \\
\text { care system } \\
\text { influencing the } \\
\text { quality of end of life }\end{array}$ & $\begin{array}{l}\text { A postal survey to } 180 \text { nursing } \\
\text { home managers. It included } \\
\text { questions about the profile of } \\
\text { deaths in the homes, access to } \\
\text { external support and barriers to } \\
\text { and perceived priorities for }\end{array}$ & $\begin{array}{l}\text { There was a } 46 \% \text { response } \\
\text { rate }(82 / 180)\end{array}$ & $\begin{array}{l}\text { Most external } \\
\text { support for end of } \\
\text { life care was } \\
\text { provided by GPs } \\
97 \% \text { of care homes } \\
\text { ( } n=58 \text { ) reported }\end{array}$ & $\begin{array}{l}\text { - } 80 \%(47) \text { of care homes } \\
\text { reported that they received } \\
\text { support from specialist } \\
\text { nurses, } 51 \% \text { from } D N s(n=30) \\
\text { and } 54 \%(n=32) \text { from } \\
\text { specialist palliative care }\end{array}$ \\
\hline
\end{tabular}




\begin{tabular}{|c|c|c|c|c|c|}
\hline $\begin{array}{l}\text { AUTHORS/TITLE } \\
\text { YEAR, (HOME TYPE) }\end{array}$ & AIMS & SURVEY DETAILS & $\begin{array}{l}\text { SAMPLE SIZE/RESPONSE } \\
\text { RATE }\end{array}$ & GP SERVICES & OTHER SERVICES \\
\hline $\begin{array}{l}\text { methods enquiry in } \\
\text { England.' } \\
2011 \text { (Seymour et al } \\
2011 \text { ) } \\
\text { Nursing homes and } \\
\text { dual registered }\end{array}$ & $\begin{array}{l}\text { care provided in } \\
\text { nursing homes. }\end{array}$ & $\begin{array}{l}\text { improving end of life care. A } \\
\text { mixed methods study - }\end{array}$ & & $\begin{array}{l}\text { that they received } \\
\text { 'some' or 'a lot' of } \\
\text { support from GPs } \\
\text { The majority of } \\
\text { responders - } 93 \% \\
\text { ( } n=76 \text { ) reported } \\
\text { liaising with } \\
\text { between } 1 \text { and } 11 \\
\text { practices (mean = 5) } \\
\text { and a range of } 1-34 \\
\text { individual GPs } \\
\text { (mean = 12) } \\
\text { Variability of } \\
\text { support from GPs } \\
\text { with end of life care } \\
\text { highlighted }\end{array}$ & $\begin{array}{l}\text { nurses. } \\
\text { - A quarter of homes did not } \\
\text { request help from specialist } \\
\text { palliative care teams } 24 \% \\
\text { ( } n=14) \\
\text { - } 66 \% \text { ( } n=53 \text { ) reported they } \\
\text { accessed palliative care } \\
\text { support via a direct advice line } \\
\text { to the local hospice or } \\
\text { Macmillan nurses. } \\
\text { - Support for residents with } \\
\text { cancer was viewed as better } \\
\text { then support given to those } \\
\text { with dementia. }\end{array}$ \\
\hline $\begin{array}{l}\text { 5. Briggs et al } \\
\text { 'Standards of medical } \\
\text { care for nursing home } \\
\text { residents in Europe'. } \\
2012 \text { (Briggs et al 2012) } \\
\text { Nursing homes }\end{array}$ & $\begin{array}{l}\text { To investigate } \\
\text { whether } 25 \text { countries } \\
\text { in Europe have } \\
\text { guidelines to } \\
\text { formalise the } \\
\text { medical care } \\
\text { delivered to older } \\
\text { people living in } \\
\text { nursing homes. }\end{array}$ & $\begin{array}{l}\text { Survey emailed to } \\
\text { representatives of } 26 \text { European } \\
\text { geriatric medicine societies } \\
\text { asking if their health service or } \\
\text { professional group: } \\
\text { 1. Requires geriatric medicine } \\
\text { training for doctors working in } \\
\text { nursing homes? } \\
\text { 2. Had written medical } \\
\text { standards for nursing home } \\
\text { care? } \\
\text { 3. Have a nursing home doctor } \\
\text { society? } \\
\text { If yes, does it have written } \\
\text { medical care standards for } \\
\text { nursing homes? }\end{array}$ & $\begin{array}{l}100 \% \text { response rate from } 25 \\
\text { geriatric medicine societies } \\
\text { in } 25 \text { European countries }\end{array}$ & $\begin{array}{l}\text { Netherlands was } \\
\text { the only country } \\
\text { where the national } \\
\text { GP society had } \\
\text { written medical } \\
\text { care standards for } \\
\text { nursing homes }\end{array}$ & $\begin{array}{l}\text { - } 5 / 25 \text { ( } 20 \%) \text { of health services } \\
\text { required specific training in } \\
\text { geriatric medicine for doctors } \\
\text { working in nursing homes. } \\
-4 / 25(16 \%) \text { geriatric } \\
\text { medicine societies had written } \\
\text { medical care standards for } \\
\text { nursing homes } \\
\text { - } 4 / 25 \text { countries had a nursing } \\
\text { home doctor society and one } \\
\text { had published medical care } \\
\text { standards for residents. }\end{array}$ \\
\hline
\end{tabular}




\begin{tabular}{|c|c|c|c|c|c|}
\hline $\begin{array}{l}\text { AUTHORS/TITLE } \\
\text { YEAR, (HOME TYPE) }\end{array}$ & AIMS & SURVEY DETAILS & $\begin{array}{l}\text { SAMPLE SIZE/RESPONSE } \\
\text { RATE }\end{array}$ & GP SERVICES & OTHER SERVICES \\
\hline $\begin{array}{l}\text { 6. British Dental } \\
\text { Association } \\
\text { 'Dentistry in care } \\
\text { homes research - UK'. } \\
2012 \text { (BDA 2012) } \\
\text { (No details) }\end{array}$ & $\begin{array}{l}\text { To investigate care } \\
\text { home residents' } \\
\text { dental care including } \\
\text { access to dentists, } \\
\text { care home staff input } \\
\text { and knowledge. }\end{array}$ & $\begin{array}{l}\text { Semi-structured in depth } \\
\text { qualitative telephone interviews } \\
\text { with a core framework of topics, } \\
\text { were conducted with managers } \\
\text { from } 13 \text { care homes and an } \\
\text { online survey was sent to } 39 \\
\text { clinical directors who reported to } \\
\text { deliver services to care homes. }\end{array}$ & $\begin{array}{l}\text { Homes chosen that covered } \\
\text { a range of sizes, ownership, } \\
\text { location and resident } \\
\text { needs. } \\
\text { No information on how } \\
\text { they were recruited and } \\
\text { how many declined to take } \\
\text { part. No mention of } \\
\text { randomisation or response } \\
\text { rates. } \\
\text { A purposive sample of } 39 \\
\text { respondents who } \\
\text { completed the annual } \\
\text { survey of Clinical Directors } \\
\text { and indicated that they } \\
\text { provided dentistry to care } \\
\text { homes, were approached to } \\
\text { take part in an online } \\
\text { survey. } 26 \text { responded, a } \\
67 \% \text { response rate. }\end{array}$ & Not applicable & $\begin{array}{l}\text { - Half of the care home } \\
\text { managers reported that their } \\
\text { residents received regular } \\
\text { check-ups. } \\
\text { - Homes were evenly split } \\
\text { between those that used high } \\
\text { street dentists and those that } \\
\text { used salaried primary care } \\
\text { dentists. } \\
\text { - Managers reported a lack of } \\
\text { information about NHS } \\
\text { providers particularly those } \\
\text { willing to provide domiciliary } \\
\text { care. } \\
\text { - Homes under the care of } \\
\text { salaried dentists were more } \\
\text { likely to have regular check- } \\
\text { ups and to receive domiciliary } \\
\text { care. }\end{array}$ \\
\hline $\begin{array}{l}\text { 7. Care Quality } \\
\text { Commission. 'Health } \\
\text { care in care homes. A } \\
\text { special review of the } \\
\text { provision of health } \\
\text { care to those in care } \\
\text { homes'. 2012(CQC } \\
\text { 2012) } \\
\text { All homes }\end{array}$ & $\begin{array}{l}\text { Provides new } \\
\text { evidence on the key } \\
\text { issues affecting older } \\
\text { people with } \\
\text { dementia living in } \\
\text { care homes }\end{array}$ & $\begin{array}{l}3 \text { questionnaire surveys } \\
\text { distributed to Alzheimer's } \\
\text { Society members (DEMFAM) and } \\
\text { care homes (DEMSTAF)- contact } \\
\text { details obtained from regulators } \\
\text { - and through some Alzheimer's } \\
\text { Society staff and online. (No } \\
\text { details of how they were } \\
\text { recruited). } \\
\text { +YOUGOV poll of UK adults }\end{array}$ & $\begin{array}{l}\text { DEMFAM (relatives of older } \\
\text { people with dementia) - } \\
1139 \text { responses } \\
\text { DEMSTAF (care home staff) } \\
\text { - } 647 \text { responses from a } \\
\text { direct mailing to } 300 \text { care } \\
\text { homes in England, Wales } \\
\text { and Northern Ireland. }\end{array}$ & $\begin{array}{l}\text { DEMFAM 56\% } \\
\text { ( } \mathrm{n}=637 \text { ) of } \\
\text { respondents said } \\
\text { access to and } \\
\text { support from GPs } \\
\text { was good, } \\
\text { DEMSTAF 55\% } \\
\text { (354) reported that } \\
\text { the resident got } \\
\text { enough support }\end{array}$ & $\begin{array}{l}\text { - DEMFAM - large numbers of } \\
\text { respondents didn't know } \\
\text { about access to dental } \\
\text { services. DEMFAM Views on } \\
\text { support from dentists was } \\
\text { mixed, only } 23 \% \text { (259) said } \\
\text { access was good. } \\
\text { DEMSTAF } 44 \% \text { (286) staff saic } \\
\text { that residents got enough } \\
\text { support from the dentist. }\end{array}$ \\
\hline
\end{tabular}




\begin{tabular}{|c|c|c|c|c|c|}
\hline $\begin{array}{l}\text { AUTHORS/TITLE } \\
\text { YEAR, (HOME TYPE) }\end{array}$ & AIMS & SURVEY DETAILS & $\begin{array}{l}\text { SAMPLE SIZE/RESPONSE } \\
\text { RATE }\end{array}$ & GP SERVICES & OTHER SERVICES \\
\hline & & $\begin{array}{l}\text { towards dementia and care } \\
\text { homes }-2060 \text { adults }\end{array}$ & & from the GP. & $\begin{array}{l}\text { - } 36 \%(408) \text { of family were } \\
\text { positive about access to and } \\
\text { support from other health } \\
\text { care services } \\
\text { - } 43 \% \text { ( } 281 \text { ) of care home staff } \\
\text { were positive about residents } \\
\text { getting enough support from } \\
\text { other services. }\end{array}$ \\
\hline $\begin{array}{l}\text { 8. Morgan and } \\
\text { Monaghan 'Wales Care } \\
\text { Home Dental Survey } \\
\text { 2010-2011'. } 2012 \\
\text { (Morgan \& Monaghan } \\
\text { 2012) } \\
\text { No details of homes }\end{array}$ & $\begin{array}{l}\text { To investigate any } \\
\text { unmet dental care } \\
\text { needs in a sample of } \\
\text { care home residents }\end{array}$ & $\begin{array}{l}\text { Designed to supplement the } \\
2009 \text { Adult Dental Health Survey } \\
\text { which excluded care homes and } \\
\text { allow for comparisons with older } \\
\text { people living at home. Clinical } \\
\text { data was collected by dentists } \\
\text { and questionnaire data on } \\
\text { service use etc by dental nurses. } \\
\text { Residents who could not consent } \\
\text { themselves were excluded. }\end{array}$ & $\begin{array}{l}228 \text { care homes randomly } \\
\text { selected and } 5 \text { residents in } \\
\text { each randomly selected to } \\
\text { take part. No details on } \\
\text { response rate and sample } \\
\text { size } \\
\text { Approximately } 708 \\
\text { residents were examined } \\
\text { and or questioned about } \\
\text { their dental care, but no } \\
\text { details were given on how } \\
\text { many participated }\end{array}$ & $\begin{array}{l}\text { Not included in this } \\
\text { survey }\end{array}$ & $\begin{array}{l}\text { - Majority of residents } \\
\text { indicated that they would only } \\
\text { attend the dentist when } \\
\text { having trouble. } \\
\text { Residents with their own } \\
\text { teeth were much less likely to } \\
\text { report regular dental check- } \\
\text { ups ( } 19 \%) \text { than older people } \\
\text { living at home. }\end{array}$ \\
\hline $\begin{array}{l}\text { 9. Morris / Barchester } \\
\text { care } \\
\text { 'Project on end of life } \\
\text { care in ten Barchester } \\
\text { care homes'. } 2012 \\
\text { (Morris 2012) } \\
\text { (Nursing homes) }\end{array}$ & $\begin{array}{l}\text { To identify good } \\
\text { practice and barriers } \\
\text { to the delivery of an } \\
\text { integrated approach } \\
\text { to end of life care in } \\
10 \text { Barchester } \\
\text { homes. }\end{array}$ & $\begin{array}{l}\text { Face to face or telephone } \\
\text { interviews with } 10 \text { care home } \\
\text { managers and } 8 \text { GPs. } \\
\text { Focus was on how GPs work with } \\
\text { care homes in relation to end of } \\
\text { life care. }\end{array}$ & $\begin{array}{l}10 \text { care home managers,- } \\
\text { assume that all those } \\
\text { approached agreed to take } \\
\text { part but need to check } \\
8 \text { GPs } 10 \text { were approached }\end{array}$ & $\begin{array}{l}\text { 9/10 care homes } \\
\text { had attached GPs, - } \\
1 \text { care home } \\
\text { worked with } \\
\text { multiple GPs } \\
4 / 8 \text { worked closely } \\
\text { with the GP the } \\
\text { other } 4 \text { had } \\
\text { problems getting } \\
\text { them to visit }\end{array}$ & $\begin{array}{l}\text { - } 7 \text { care homes had access to } \\
\text { palliative care services } \\
\text { - } 3 \text { care homes had access to } \\
\text { the district nurse } \\
-2 \text { care homes had access to } \\
\text { the old age psychiatrist } \\
-1 \text { care home had access to } \\
\text { the geriatrician }\end{array}$ \\
\hline
\end{tabular}




\begin{tabular}{|c|c|c|c|c|c|}
\hline $\begin{array}{l}\text { AUTHORS/TITLE } \\
\text { YEAR, (HOME TYPE) }\end{array}$ & AIMS & SURVEY DETAILS & $\begin{array}{l}\text { SAMPLE SIZE/RESPONSE } \\
\text { RATE }\end{array}$ & GP SERVICES & OTHER SERVICES \\
\hline $\begin{array}{l}\text { 10. Sackley et al 'The } \\
\text { availability and use of } \\
\text { allied health care in } \\
\text { care homes in the } \\
\text { Midlands, UK (Sackley } \\
\text { et al 2009). } \\
\text { All homes }\end{array}$ & $\begin{array}{l}\text { To establish the } \\
\text { access to and use of } \\
\text { services provided by } \\
\text { allied health } \\
\text { professions to care } \\
\text { homes in Oxfordshire } \\
\text { and Warwickshire }\end{array}$ & $\begin{array}{l}\text { Cross-sectional postal survey } \\
\text { design focused on use of service, } \\
\text { frequency of use, referral } \\
\text { mechanisms, funding and most } \\
\text { common problems service } \\
\text { sought for. } \\
\text { Allied health care services } \\
\text { included in the survey were } \\
\text { physiotherapy, occupational } \\
\text { therapy, chiropody, dietetics, } \\
\text { optometry, speech and language } \\
\text { therapy, complementary } \\
\text { (alternative) therapy, hearing } \\
\text { services and social activity } \\
\text { organisation services. }\end{array}$ & $\begin{array}{l}115 / 121 \text { care homes } \\
\text { returned the questionnaires } \\
\text { or completed them by } \\
\text { phone, a } 95 \% \text { response rate }\end{array}$ & $\begin{array}{l}\text { Not included in this } \\
\text { survey }\end{array}$ & $\begin{array}{l}\text { - The majority of homes } \\
\text { reported using a chiropodist } \\
(91 \%) \text {, an optician ( } 86 \%) \text {, } \\
\text { hearing services (63\%) and a } \\
\text { physiotherapist (65\%). } \\
\text { - Less than half reported using } \\
\text { an occupational therapist } \\
\text { (41\%), dietician (44\%), speech } \\
\text { and language therapist (39\%). } \\
\text { - A third used an alternative } \\
\text { therapist (35\%) and social } \\
\text { activities organiser (35\%). } \\
\text { - The sources of funding for } \\
\text { these services were complex } \\
\text { and variable with up to fifteen } \\
\text { variations. A high proportion } \\
\text { of allied health care access } \\
\text { was privately funded } \\
\text { - Referral mechanisms were } \\
\text { also complex. Many homes } \\
\text { were unsure of how to refer } \\
\text { to the NHS and social services. }\end{array}$ \\
\hline
\end{tabular}




\section{DISCUSSION}

We found 15 recent surveys of working arrangements between the NHS and care homes, of which five were primarily focussed on primary care whilst ten focussed on specialist services. Different patterns of GP working were noted, including the use of payments above and beyond those in the standard GP contract. Access to a large variety of health professionals and services was found (for example, with eight different types of nurse) but access seemed to vary markedly. Access to dentistry was poor.

The wide variation in organisation, provision and funding of both enhanced generalist and specialist services to care homes is likely to persist as clinical commissioning groups develop and seek solutions that address local needs. Localism may actually be to the advantage of the care home sector given that it too varies between regions. There is the possibility that GP commissioners can now respond more strategically to their local needs. For example, care homes in Nottinghamshire were reported as having more access to community pharmacists than found in other surveys. Nevertheless, commissioners have first to recognise that the sector requires special consideration. Although there was some evidence from the surveys of the development of care home-specific services, these were the minority and it was impossible to establish how many residents they supported. Similarly, geriatric medicine departments input to care homes was predominantly in response to referrals and requests rather than proactive with dedicated staff time for care home work. The surveys we found did not explore access to mental health services in detail, but an earlier study by Purandare and colleagues of 1689 home managers who responded to a Postal survey sent to a random sample of care homes in the UK suggests that around a half had input from social workers and psychologists, and two thirds were supported by old age psychiatrists and community psychiatric nurses (Purandare et al 2004).

Care homes that are members of corporate chains may benefit from the company's managerial depth to both influence access to NHS generalist and specialist services, and supplement gaps by residents' payments for in-house provision (for example, podiatry). In Bowman's study of 204 Nursing and dual registered homes (Bowman 2005), the homes were well supported by NHS services with more than $80 \%$ receiving most services, including palliative care, and over 90\% receiving input from dieticians, physiotherapy, dentistry, continence advisors, CPNs, opticians, pharmacists, podiatrist and speech and language therapists (SALTs). In another survey access to community NHS services and the quality of 
service received were reported to be better after relocation to a care home (Seymour et al 2011) [Error! Bookmark not defined.].

Care home residents arguably represent a large, underserved population with extensive unmet needs. By bringing these diverse studies together we have identified that the issues are not localised or limited but generalised and replicated across the country, regardless of whether surveys are conducted by the NHS, voluntary sector, care home. There appears to be uncertainty about where roles and responsibilities are shared. Where shared, the lines of demarcation are subject to local negotiation and where such negotiation is not explicitly conducted, gaps, rather than overlaps, characteristically appear in service provision (Gordon et al 2013). It is also likely that, historical differences in local funding of NHS services, different patterns of innovation within the NHS, and variable levels of organisation inside the care home sector have shaped patterns of service delivery. While this review of surveys cannot differentiate between these factors, it does highlight the need for commissioners to be aware of, and respond to them in specifying an appropriate service for care homes looks like.

Strengths \& limitations of the study: This is the most comprehensive review to date of what is known about the working relationships between the NHS and the care home sector. The details of its findings should be interpreted with caution, given the variable survey methods, wide range of recruitment methods, different sample sizes and different depths of detail in the 16 studies. The methods were suitable for finding survey material not in electronic databases, but there is a possibility that there are other surveys that have been conducted that we were unable to locate. However, in our view it is likely that they would only increase the evidence in support of our main findings about variety and diversity. Our deductions from the surveys are limited by the quality of the surveys themselves, and being in the grey literature implies that they were not conducted with the rigour of research. For example, it is not clear whether "regular visits from a community geriatrician" means exactly that or simply access to one. Similarly, surveys did not distinguish between NHS-provided physiotherapy and private physiotherapy, or between "group" and "individual" physiotherapy. Care homes may report that they organise a "private physiotherapist" for their residents when they are, in fact, purchasing chair-based exercises that take place regularly in the dayroom. Local surveys may refer to local services whose functions are uncertain, as there is no common and accepted terminology or taxonomy for community health services. This, and the diversity in provision, makes it hard to provide precise figures about levels of provision or meaningful averages. 
Implications for commissioning: Care homes provide a crucial role supporting a vulnerable, frail population. Services commissioned for care are insufficiently comprehensive (e.g. they miss podiatry, dentistry, physiotherapy), co-ordinated (predominantly reactive rather than pro-active) or expert (limited access to specialist expertise in old age psychiatry and geriatric medicine). Commissioners need to ensure that older people in care homes currently receive age appropriate timely and equitable care as required by the Equality Act (2010), and to make explicit how services can be accessed and the criteria against which performance is measured. There is a strong case to establish what is and what is not covered by the General Medical Service contract for general practice, to consider means of assuring compliance with the contract, as well as considering the adequacy of the contractual obligations. If more GP input is required there should be a mechanism for this to occur ubiquitously rather than fortuitously.

Implications for research: Given the heterogeneity of services delivered to care homes, the lack of evidence-based explanations for this variation, the lack of comparative outcome or resident experience data, and the instability of the current configurations, several research questions emerge:

- What organisational characteristics (of the NHS and of care homes) are associated with better outcomes?

- What clinical processes facilitate the achievement of best outcomes (identification of at risk patients, use of care pathways etc.)?

- What commissioning arrangements best secure and sustain the optimal service pattern (e.g. incentive payments, integrated clinical governance)?

- How do local circumstances such as size of home and case-mix of residents affect these factors?

To date evaluation has focused on single initiatives or new models of service delivery. There is a need for a comparative analysis that can explore the associations of service delivery patterns with contextual care homes factors and different ways of working in order to clarify the optimal commissioning decisions to provide equitable care for residents. There is a question about the utility of conducting further surveys for academic purposes, or even for local service development purposes. Researchers should try to develop and consistently use a taxonomy for health care services for care homes and their residents.

\section{Conclusions:}


The number of surveys identified and the consistent nature of their findings, despite their methodological diversity, indicates that there is no need for further, descriptive surveys of the inadequacies of existing provision. However, there is a need to know what is achieved by NHS input to care homes (GPs, community nursing, AHP and specialist services) and which models of service delivery are most effective. The absence of a national minimum data set on the health-related characteristics of residents in care homes (as is available in the US) makes it difficult to judge the relationship between service provided and needs observed. Nevertheless, over the decade since the first national survey of health care provision to care homes (Jacobs et al 2001), the findings summarised in this paper demonstrate the need to move beyond surveying or auditing the status quo. We suggest that this calls for a robust and testable framework for understanding the relationship between the NHS and care homes. This is required before we can specify different 'models of care', in order to compare their effectiveness in relation to outcomes and costs.

\section{Acknowledgements}

This research was funded by NIHR Health Service Delivery and organisation (HSDR 11/021/02).

The views and opinions expressed therein are those of the authors and not necessarily reflect those of the NIHR HSDR or the Department of Health. 


\section{REFERENCES}

Alzheimer's Society 2007 Home from home: quality of care for people with dementia living in care homes. Alzheimer's Society London

BDA 2012 Dentistry in care home research -UK British Dental Association Research Unit, London

BGS 2011 Quest for Quality: Joint working party inquiry into the quality of health care provision for older people in care homes British Geriatrics Society London 2011

BGS 2013. BGS Commissioning Guidance: High quality health care for older care home residents. British Geriatrics Society London

http://www.bgs.org.uk/campaigns/2013commissioning/Commissioning 2013.pdf (accessed $12 / 08 / 14)$

Bowman, C. 2005 Health Service Support to Care Homes. Unpublished report commissioned by the British United Provident Association (BUPA).

Briggs R, Robinson S, Martin F, O'Neill D 2012 Standards of medical care for nursing home residents in Europe. European Geriatric Medicine; 3 (2012) 365-367

Carter C. 2011 Failing the Frail: A Chaotic Approach to Commissioning Healthcare Services for Care Homes. British Geriatrics Society. Available online at http://bit.ly/17EkyBI (accessed $12 / 8 / 14)$

Chikura G, 2010 Care homes project. Unpublished report commissioned by Nottinghamshire County NHS.

CQC 2012 Health care in care homes. A special review of the provision of health care to those in care homes Care Quality Commission London http://www.cqc.org.uk/content/review-healthcare-services-care-home-residents-published (accessed 12/8/14).

Darton, R. 2011 Study of care home residents' and relatives' expectations and experiences. PSSRU, University of Kent, for the Registered Nursing Home Association www.rnha.co.uk/web images/pdfs/pssru report may2012rev.pdf (accessed 12/8/14)

Davies,S.I., Goodman, C., Bunn,F. Victor C, Dickinson A, Iliffe S, Gage H, Martin W, Froggatt K 2011 A systematic review of integrated working between care homes and health care services.BMC Health Services Research,11:320

Donald IP, Gladman J, Conroy S, Vernon M, Kendrick E, Burns E. 2008 Care home medicine in the UK--in from the cold. Age Ageing;37(6):618-20. 
ECCA 2008 Can We Afford the Doctor? GP Retainers and Care Homes English Community Care Association London http://www.scie-socialcareonline.org.uk/can-we-afford-the-doctorgp-retainers-and-care-homes/r/a11G00000017zdxIAA (accessed 12/8/14)

Gage H., Goodman C., Davies,S.L Norton C, Fader M, Wells M, Morris J, Williams P. 2010 Laxative use in care homes J Advanced Nursing 66(6):1266-72

Gage, H., Dickinson, A., Victor, C., Williams, P., Cheynel, J., Davies, S.L., Iliffe, S., Froggatt, K., Martin, W., Goodman, C., 2012 Integrated working between residential care homes and primary care: a survey of care homes in England. BMC Geriatrics 12 (1), 71

Gladman J. 2010 Provision of medical care in UK care homes. Medical Crises in Older People discussion paper series. Issue 1 University of Nottingham. Available at: http://www.nottingham.ac.uk/mcop/documents/papers/issue1-mcop-issn2044-4230.pdf (accessed 12/8/14)

Glendinning C. Jacobs S.,Alborz A Hann M 2002. A survey of access to medical services in nursing and residential homes in England British Journal of General Practice $52,480: 545-549$

Goodman C. and Davies S. 2011 Good practice outside care homes in Milne A and Dening T.(eds) Mental Health and Care Homes Oxford University Press

Goodman C. Robb N. Drennan V. and Woolley R. 2005 Partnership working by default: district nurses and care home staff providing care for older people Health and Social Care in the Community;13(6) 553-62

Goodman C., Woolley R, Knight D. 2003 District nurses' experiences of providing care in residential homes: issues of context and demand Journal of Clinical Nursing;12(1):67-76

Goodman, C,, Davies,S. Dickinson A.,Froggatt, K , Gage,H. Iliffe, S. Martin,W, Victor,C. 2013 A study to develop integrated working between primary health care services and care homes Health Service Delivery and Research Programme www.nets.nihr.ac.uk/projects/hsdr/081809231 (accessed 12/8/14)

Goodman,C. Mathie,E.J. Cowe,M Mendoza,A. Westwood,D. Munday,D. Wilson,P.M. Crang,C Froggatt,K Iliffe,S Manthorpe,J Gage,H, Barclay S 2011: Talking about living and dying with the oldest old: public involvement in a study on end of life care in care homes. BMC Palliative Care;10:20

Gordon A, Dyas J, Logan P, Gladman J. 2013 Explaining the barriers to and tensions in delivering effective healthcare in UK care homes: a qualitative study. BMJ Open 19;3(7) 
Gordon Al, Franklin M, Bradshaw L, Logan P, Elliott R, Gladman J R. Health status of UK care home residents: a cohort study. Age Ageing. 2013; 17. Epub ahead of print

Hayes N, Martin F. 2004 Supporting care homes: the older people's specialist nurse. $\mathrm{Br} J$ Nurs.;13(21):1250-7

Jacobs, S., Alborz, A, Glendinning, C, Hann M 2001 Health Services for homes. A survey of access to NHS services in nursing and residential homes for older people in England. NPCRDC Report, University of Manchester

Joseph Rowntree Foundation 2008. Providing nursing support within residential care homes. Joseph Rowntree Foundation ISSN 0958-3084.

Lawrence, V. \& Banerjee, S. 2010 Improving care in care homes: a qualitative evaluation of the Croydon Care Home Support Team. Aging and Mental Health.; 14 (4), 414-42;

Monaghan N \& Morgan M 2010 Oral Health Policy and access to dentistry in care homes. Journal of Disability and Oral Health 11(2) 61-68.

Morgan M \& Monaghan N 2012 Oral health and dental care in residential and nursing homes in Wales 2010-2011.

http://www.senedd.assemblywales.org/documents/s4509/Consultation\%20response\%20RC \%2014\%20-(accessed 12/8/14)

Morris. J 2008 Service Review of Barchester Care Homes. Unpublished report commissioned by Barchester Healthcare Ltd.

Purandare N, Burns A, Challis D, Morris J. 2004 Perceived mental health needs and adequacy of service provision to older people in care homes in the UK: a national survey. International Journal of Geriatric Psychiatry;19: 549-553

Quince, C 2013 Low expectations: Attitudes on choice, care and community for people with dementia in care homes. Alzheimer's Society.

http://www.alzheimers.org.uk/site/scripts/download_info.php?downloadID=1024 (accessed $12 / 8 / 14)$

Robbins I, Gordon A, Dyas J, Logan P, Gladman J. 2013 Explaining the barriers to and tensions in delivering effective healthcare in UK care homes: a qualitative study. BMJ Open. Jul 19;3(7)

Sackley, C, Hoppitt, T, Cardoso, K, Levin, S 2009. The availability and use of allied health care in care homes in the Midlands, UK. International Journal of Therapy and Rehabilitation; 16(4) $218-222$ 
Seymour JE, Kumar A, Froggatt K. 2011 Do nursing homes for older people have the support they need to provide end of life care? A mixed methods enquiry in England. Palliative Medicine;25 (2) 125-138.

Steves CJ, Schiff R, Martin FC. 2009 Geriatricians and care homes: perspectives from geriatric medicine departments and primary care trusts. Clinical Medicine;9(6):528-33

Szczepura, A., Nelson, S, Wild, D. 2008 In-reach specialist nursing teams for residential care homes: uptake of services, impact on care provision and cost effectiveness. BMC Health Services Research 8: 269

Szczepura, A., Wild, D., Nelson, S., 2011 Medication administration errors for older people in long-term residential care. BMC Geriatrics Dec 7;11:82

Thompsell A. 2011 Support to Care Homes in Dening and Milne (eds) Mental Health and Care Homes Oxford University Press. 